\title{
Acquisition of Some Selected Prepositions of Time by English Major Undergraduates at Balqa Applied University in Jordan
}

\author{
Ayat Khalid Al-Qudah ${ }^{1}$ \\ ${ }^{1}$ Ajloun University College, Balqa Applied University, Ajloun, Jordan \\ Correspondence: Ayat Khalid Al-Qudah, Ajloun University College, Balqa Applied University, Ajloun, Jordan. \\ E-mail: khalid_qudah@yahoo.com
}

Received: May 26, 2013 Accepted: June 20, 2013 Online Published: August 15, 2013

doi:10.5539/elt.v6n9p97 URL: http://dx.doi.org/10.5539/elt.v6n9p97

\begin{abstract}
This study aimed to identify the acquisition of some selected prepositions of time by English major undergraduates at Balqa Applied University in Jordan and to reveal any significant differences among their acquisition attributed to the academic level $\left(1^{\text {st }}, 2^{\text {nd }}, 3^{\text {rd }}\right.$ and $4^{\text {th }}$ year levels $)$ and to studying "English Basic Grammar" course. A random sample consisted of 197 students chosen from two colleges at Balqa Applied University in the year 2012/2013. The instrument was developed by the researcher. Results indicated that their highest acquisition was in the preposition of time (at) and the lowest acquisition was in the preposition of time (until). Findings also revealed the mean of acquisition of the prepositions of time was lower than (0.50). Findings also indicated that there is a significant difference among respondents' acquisition of the prepositions of time attributed to year-level in three prepositions (at, to, since) in favor of the third year level students, and difference in the acquisition of (on) in favor of the fourth year level students and a significant difference in the acquisition of (after) in favor of the second year level students. The results indicated no significant differences in acquisition attributed to the university college, but there significant difference among respondents' acquisition attributed to studying the course 'Basic English Grammar' in favor of the students who studied the course. The study was concluded with some recommendations.
\end{abstract}

Keywords: acquisition, prepositions, undergraduates, Balqa Applied University, Irbid University College, Ajloun University College

\section{Introduction}

Prepositions are words or groups of words that typically come before a noun phrase and indicate syntactic relations. (Mathews, 1997). Agoi (2003) described prepositions as a or group of words used with a noun or noun equivalents to show the link between that noun which it governs and another word. Hamdallah and Tushyeh (1988) stated that prepositions are function words that link words, phrases, or clauses to other words in the sentence.

However, prepositions are often vague and confusing, how to understand and use them especially for EFL and ESL learners for many reasons. While learning the new language, they are also applying some rules from their first language (L1) onto the target language (L2), a phenomenon known as learning transfer. This transfer can be either negative interference or positive interference. Each language has its own rules which creat problems for the learners of a foreign language. Thahir (1987) indicates that prepositions can cause a problem for Arabic learners of English. What makes it harder for Arab learners of English to master English preposition usage is that Arabic prepositions are more limited in number than those of English. Abbas (1961) says that there are only twenty prepositions in Arabic but Hayden (1956) says that English has fifty seven prepositions. Grubic (2004) concluded that speakers of English as a foreign language encounter three problems with prepositions: using the incorrect preposition, or deleting the necessary preposition or using a $\mathrm{n}$ additional preposition.

Several Arab researchers reported and confirmed that Arab EFL learners in general and Jordanian EFL learners in particular, face difficulty in using English prepositions. (Rababah, 2003; Zughous, 2003; Tahaineh, 2010; Fion, 2005; Onike, 2007; Jalati, 2012; Al-Marrani, 2009; Tahaineh, 2010) described learning English prepositions as a perpetual problem for Arab EFL learners. Hamdallah and Tushyeh (1988) concluded that (EFL) Arab learners of English language encounter difficulty in learning English since both English and Arabic languages belong to two different language families. 


\subsection{Statement of the Problem}

Research (e.g. Thahir, 1987; Rababah, 2003; Zughoul, 2003; Fion, 2005; Onike, 2007; Al-Marrani, 2009; Boquist, 2009; Tahaineh, 2010; Jalal and Shojaei, 2012) has shown that prepositions are often difficult for students to learn as a foreign language. Most researchers called for further research to be conducted on prepositions. The researcher has not found a study conducted on acquisition of prepositions of time by English major undergraduates at Balqa Applied University in particular or at Jordanian Universities at large. Therefore, this study attempts to investigate the acquisition level of some selected prepositions of time by English major undergraduates at Balqa Applied University in Jordan. This study attempts to answer the following questions:

1) What are the levels of acquisition of the English major undergraduates at Balqa Applied University in the selected prepositions of time?

2) Are there any significant statistical differences at $(\alpha=0.05)$ level in the acquisition of the selected prepositions of time among English major undergraduates at Balqa Applied University attributed to the academic level $\left(1^{\text {st }}\right.$, $2^{\text {nd }}, 3^{\text {rd }}$ and $4^{\text {th }}$ year levels)?

3) Are there any significant statistical differences at $(\alpha=0.05)$ level in the acquisition of the selected prepositions of time between English major undergraduates at Balqa University attributed to studying English Basic Grammar course?

\subsection{The Significance of the Study}

The importance of the study stems from the topic it deals with, which aims to identify the acquisition levels of the English major undergraduates at Balqa Applied University in Jordan. It is hoped that the study will give insights to Jordanian teachers at schools and English instructors at universities in the use of prepositions of time, and to focus on them in the learners' linguistic input and instruction at both school and college levels.

It is also hoped that the findings of the study will have a bearing on curriculum design and development. Besides, the importance of this study lies in the fact that it sheds light on a neglected area of language acquisition which is prepositions of time. It, thus may encourage researchers to conduct further research on different types of prepositions and their acquisitions, and to provide learners and teachers of English with useful hints and recommendations.

\section{Review of Related Literature}

Zughoul (1979) emphasized that Arab EFL learners face special problems in learning English prepositions: I Traditional methods of teaching such as the grammar translation method which encourages students to translate in their minds, and (2) the interference from their native language, Arabic; and (3) the English preposition is not always expressed in Arabic by a preposition, its equivalent may be a different part of speech.

Scott and Tucker (1974) indicate that that English prepositions rarely correspond to Arabic prepositions. Their study revealed that approximately two thirds of the errors in prepositions seemed to be attributable to native- language Arabic and one third interference; redundant use of prepositions had its source chiefly in Arabic. Substitution of prepositions stemmed from both Arabic and English forms. They concluded that Arab EFL learners learn the semantic meaning of the English lexical prepositions before they learn all the restrictions on their usage.

Hashim (1996) surveyed most of the studies conducted on syntactic errors, which Arab EFL students made. He found that a lot of errors the students made were syntactic and the influence of the mother tongue was the main cause of errors.

Kharma and Hajjaj (1997) have reported in their study on Arab EFL learners' errors, that the majority of their errors are in English syntax they thought learning English prepositions by Arab learners was a perpetual problem, and in particular, prepositions are the most troublesome aspect of syntax.

Hamdallah and Tushyeh (1988) conducted a contrastive analysis of selected English and Arabic prepositions with pedagogical implications and found out that prepositions constitute a learning difficulty especially to the nonnative speaker of English in general, and to the EFL learners because they are fewer in Arabic and their usage differs.

Onike (2007) examined the misuse of prepositions by the learners of English language especially under second language learning situation. The results indicate that interference factor constitutes a problem of usage to most learners of English language especially in second language learning situation.

Catalan, R.M.J (1996) studied frequency and variability in errors in the use of English prepositions. The sample of the study consisted of 290 essays written by third year students of English as a foreign language from three Spanish 
secondary schools in Madrid, Spain. They were 118 males and 172 females. The results indicate that English prepositions are difficult for the students. She found that substitution errors are more common than omission and addition errors. She also concluded that English prepositions must be considered a difficult area for Spanish learners of English.

Fion (2005) studied the acquisition of English spatial prepositions (in, on, at) by ESL Chinese learners. The results reveal three major problems that the ESL learners encounter including: 1) the interpretation of the function of the spatial prepositions; 2) the overlook of the preposition (at) and 3) the difficulties in the learning of the idiom. They tend to use fewer times the preposition (at) than otherwise should because it is more abstract than the other two. ESL learners have found out that acquiring the idioms are the worst and most difficult for them to learn because they are more abstract.

Sudhakaran (2008) studied the use of prepositions among Malay adult ESL learners. This study was carried out on seven Malay students from the International Islamic University Malaysia. He analyzed the students' use of prepositions in speaking and writing. The results revealed that the students made more errors of commission than errors of omission. The students did best in (for, in ,about)prepositions in speaking tasks and did best in (to , of , in )prepositions in writing tasks.

Al-Marrani (2009) conducted a comparative study of prepositions in Arabic and English. The results indicate that there are similarities and differences between these two subsystems of the prepositions of Arabic and English. The similarities between them facilitate the development process of learning English language (positive transfer or interference); whereas differences make learning process of English language difficult and as a result Arab learners make many mistakes (negative transfer or interference).

Boquist (2009) conducted a study on the second language acquisition of English prepositions by trying to introduce a new approach for teaching prepositions to the second language learners of English. The results indicate that prepositions are quite difficult to be acquired by the second language learners for several reasons. First, the nature of the second language acquisition creates certain clash points, prepositions constitute part of these clash points. Nevertheless, few textbooks address the problem.

Tahaineh (2010) investigated Arab EFL universities students' errors in prepositions usage. Data was collected from free compositions written by a random sample of 162 English major undergraduates at Al-Balqa Applied University in Jordan. Findings revealed that mother tongue interference is the main cause of EFL learners' errors $(58 \%=1323)$. However, transfer strategies of the target language itself are also examined and formed a main source of the errors too $(42 \%=967)$. Results indicated that Arab learners of English use the right prepositions if equivalent prepositions are used in their mother tongue.

Abbas and Karimnia (2011) analyzed grammatical errors made by Iranian students of translation. They examined a number of grammatical errors that were committed by Iranian students in their translation and compared the errors of junior and senior students to identify the errors which had been corrected during their study at the university. They examined the errors of 40 senior and 40 junior students of translation at Azad and Payam-e-Noor University in Iran in 2009/2010. They classified the errors into two categories. Findings revealed significant shortfalls in English grammar and that $98 \%$ of the respondents had grammatical problems caused mainly by inter-lingual influence.

Jalali and Shojaei (2012) analyzed the errors that the Persian EFL learners made in composition. 78 English translation undergraduates were chosen from Payam Noor University, The students were divided into three groups according to their English proficiency test scores Each participant wrote four compositions, which formed a total sample of 312 compositions. The findings indicated 15 prepositional error types were identified. Most of the students suffered from perpetual problems in the use prepositions.

Alayesh (2012) studied the effect of understanding Arabic prepositions on the use of English prepositions. The data was drawn from non-department students in the faculty of Education at Misurata University in Libya to identify the main source of difficulties which the students encounter in using English prepositions. The students have been tested before and after explaining the different meanings of Arabic prepositions to them. The analysis of data revealed that understanding the different meaning of Arabic prepositions can eliminate the misuse of many English prepositions.

The literature review shows that the previous studies either dealt

a) With the negative side of interference of mother tongue in learning English prepositions as indicated by (Scott and Tucker, 1974; Zughoul, 1979; Hisham, 1996; Onike, 2007; Al-Marrani, 2009; Boqurst, 2009; Tahaineh, 2010; Abbas and Karimnia, 2011).

b) Or with investigation and analysis of EFL/ ESL learners' errors in the use of English prepositions as indicated 
by (Hamdallah Tushyeh, 1988; Kharma and Hajjas, 1997; Catalan, 1996; Onike, 2007; Tahaineh, 2010; Abbas and Karimnia, 2011; Jalali and Shojaei, 2012).

c) Or with the positive interference of mother tongue in learning English prepositions as indicated by (Scott and Tucker, 1974; Al-Marrani, 2009; Tahaineh, 2010; Alayesh, 2012).

d) Or with Arab EFL learners as indicated by (Scott and Tucker, 1974; Kharma and Hajjaj, 1997; Al-Marrani, 2009; Tahaineh, 2010; Alayesh, 2012).

E-or with contrastive analysis of Arabic and English prepositions as indicated by (Hamdallah and Tushyeh, 1988; Al-Marrani, 2009; Alayesh, 2012). To the knowledge of the researcher, this is the first study conducted on prepositions of time in Jordan and the Arab World, which investigates the acquisition level of prepositions of time among undergraduate English major students at Balqa Applied University in Jordan.

\section{Methodology}

The Sample of the Study: A random sample of 197 female students chosen from two colleges, Ajloun University College and Irbid University College in the academic year 2012/2013. Both colleges belong to Balqa Applied University. Distributions of the sample according to college, academic year level and to studying English Basic Grammar course are shown in tables (1-3).

Table 1 . The sample of the study distributed according to college

\begin{tabular}{lll}
\hline College & Frequency & Percent \\
\hline Ajloun & 117 & 59.4 \\
Irbid & 80 & 40.6 \\
\hline Total & 197 & 100 \\
\hline
\end{tabular}

As shown in Table 1, the sample of the study included 117 female students from Ajloun university college and 80 female students from Irbid university college.

Table 2. The sample of the study distributed according to the academic level

\begin{tabular}{|c|c|c|c|}
\hline \multicolumn{2}{|c|}{ Academic Level } & Frequency & Percent \\
\hline $1^{\text {st }}$ Year & 79 & & 40.1 \\
\hline $2^{\text {nd }}$ Year & 56 & & 28.4 \\
\hline $3^{\text {rd }}$ Year & 43 & & 21.8 \\
\hline $4^{\text {th }}$ Year & 19 & & 9.6 \\
\hline Total & 197 & & 100.0 \\
\hline
\end{tabular}

As shown in Table 2, the sample of the study included 79 first year students, 56 second year students, 43 third year students, and 19 fourth year students.

Table 3. The sample of the study distributed according to studying the basic English grammar course

\begin{tabular}{lll}
\hline Basic English Grammar Course & Frequency & Percent \\
\hline Students who Studied the Course & 160 & 81.2 \\
Students who did not study the course & 37 & 18.8 \\
\hline Total & 197 & 100.0 \\
\hline
\end{tabular}

As shown in Table 3, the sample of the study included 160 students who studied the basic English grammar course and 37 students who didn't study it. 


\subsection{Instrument}

The researcher developed an instrument to identify the acquisition level of some selected prepositions of time by English major undergraduates at Balqa Applied University in Jordan. The instrument consists of two parts. The first part requires respondents to provide personal data, and whether they studied "Basic English Grammar" course. The second part is designed to identify the respondents the acquisition level of (12) selected prepositions of time.

\subsection{Validity}

8 faculty members of the participating colleges reviewed the questionnaire and offered suggestions. As a result, a few items were cancelled and some items were modified.

\subsection{Reliability}

Alpha coefficient of the second part of the instrument was (0.90). Reliability coefficient is quite satisfactory for the purpose of the study.

\subsection{Procedures}

Eight judges reviewed the instrument. According to their feedback, some items were cancelled; some items were rewritten where necessary and some were added. The judges validated the modified instrument before it was administered to the respondents by the researcher, who helped them fill out the forms and answer any questions asked by them.

The data were collected in the first semester, October 2011Statistics such as means and standard deviations were used. The t-test and one way analysis, were used to answer the questions of the study.

\subsection{Variables of the Study}

The independent variables were: the academic level $\left(1^{\text {st }}\right.$ year, $2^{\text {nd }}$ year, $3^{\text {rd }}$ year and $4^{\text {th }}$ year, and whether the respondents have studied (Basic English Grammar) course the university.

\subsection{Data Analysis}

To answer the first question, which aimed to identify the levels of acquisition of the selected prepositions of time by the English major undergraduates at Balqa Applied University, percentages were used. To answer the second question which aims to identify the types and causes of errors made by the English major undergraduates at Balqa Applied University when using the selected prepositions of time, percentages were employed. To answer the third question, which aimed to reveal if there are any significant statistical differences at $(\alpha=0.05)$ level in the acquisition of the selected prepositions of time among English major undergraduates at Balqa Applied university attributed to the academic level means, standard deviation and ANOVA analysis were used. to answer the fourth question, which aims to reveal if there are any significant statistical differences at $(\alpha=0.05)$ level in the acquisition of the selected prepositions of time among English major undergraduates at Balqa Applied University attributed to studying Basic English Grammar course at the university, t-test was used.

\section{Discussion of the Results}

Results of the first question (what are the levels of acquisition of the selected prepositions of time by the English major undergraduates at Balqa Applied University?) are shown in tables (5-7).

Table 4. Levels of acquisition of the selected prepositions of time of respondents ordered by rank according to means and standard deviation from highest to lowest. $(\mathrm{N}=197)$

\begin{tabular}{lllll}
\hline Rank & $\mathrm{N}$ & Preposition & Mean & S.D. \\
\hline 1 & 197 & at & .63 & .251 \\
2 & 197 & to & .60 & .365 \\
3 & 197 & in & .56 & .273 \\
4 & 197 & for & .54 & .345 \\
5 & 197 & after & .51 & .297 \\
6 & 197 & before & .50 & .323 \\
7 & 197 & during & .45 & .318 \\
8 & 197 & from & .44 & .329 \\
9 & 197 & since & .42 & .318 \\
10 & 197 & on & .41 & .282 \\
11 & 197 & while & .41 & .283 \\
12 & 197 & until & .29 & .263 \\
\hline
\end{tabular}


Table 4 indicates that the preposition of time (at) with a mean of. 63 ranked first among all the selected prepositions of time in this study. It also indicates that the preposition of time (until) with a mean of. 29 occupies the last rank in this study. Findings reveal that the means of the acquisition of the prepositions by the English major undergraduates at Balqa Applied university is lower than (.50). This finding emphasizes that acquisition of prepositions of time constitutes a big problem and a great difficulty for Arab Jordanian students. This finding is consistent with the following studies (Hamdallah and Tushyeh, 1988; Catalan, 1996; Hajjaj, 1997; Fion, 2005; Boquist, 2009; Tahaineh, 2010).

Table 5. Levels of acquisition of the selected prepositions of time ordered by rank according to means and standard deviation from highest to lowest at Ajloun University College $(\mathrm{N}=117)$

\begin{tabular}{lllll}
\hline Preposition & Rank & Number & Mean & S.D. \\
\hline at & 1 & 117 & .66 & .240 \\
to & 2 & 117 & .59 & .369 \\
for & 3 & 117 & .54 & .348 \\
in & 4 & 117 & .53 & .293 \\
after & 5 & 117 & .51 & .292 \\
before & 6 & 117 & .48 & .318 \\
during & 7 & 117 & .48 & .310 \\
from & 8 & 117 & .46 & .333 \\
since & 9 & 117 & .44 & .322 \\
on & 10 & 117 & .43 & .292 \\
while & 11 & 117 & .43 & .286 \\
until & 12 & 117 & .29 & .253 \\
\hline
\end{tabular}

Table 5 shows that the preposition of time (at) ranked first among all the selected prepositions of time at Ajloun University College. It also shows that the preposition of time (until) occupied the lowest rank in this study.

The findings indicate that the preposition of time ( $a t$ ) occupies the highest rank among all the selected prepositions of time at Ajloun University College. The preposition of time (until) occupies the lowest rank among the selected prepositions of time both at Balqa Applied University and the lowest rank at Ajloun University College.

Table 6. Levels of acquisition of the selected prepositions of time ordered by rank according to their means and standard deviation from highest to lowest at Irbid University College $(\mathrm{N}=80)$

\begin{tabular}{lllll}
\hline Preposition & Rank & Number & Mean & S.D. \\
\hline to & 1 & 80 & .62 & .354 \\
in & 2 & 80 & .60 & .237 \\
at & 3 & 80 & .59 & .262 \\
for & 4 & 80 & .56 & .342 \\
before & 5 & 80 & .52 & .331 \\
after & 6 & 80 & .51 & .305 \\
from & 7 & 80 & .42 & .323 \\
during & 8 & 80 & .41 & .327 \\
since & 9 & 80 & .40 & .312 \\
while & 10 & 80 & .39 & .278 \\
on & 11 & 80 & .38 & .267 \\
until & 12 & 80 & .29 & .277 \\
\hline
\end{tabular}

Table 6 shows that the preposition of time (to) ranked first among all the prepositions of time at Irbid university College. It also indicates that the preposition of time (until) ranked lowest among all the prepositions of time in this study. Table 6 indicates that the highest rank (to) is different from the highest rank in tables 4 and 5 . Tables 4 , 5 and 6 indicate that the lowest rank is occupied by the preposition of time (until).

In answering the second question (Are there significant differences at $(\alpha=0.05)$ level in the acquisition of the selected prepositions of time among English major undergraduates at Balqa Applied University attributed to the academic level $\left(1^{\text {st }}, 2^{\text {nd }}, 3^{\text {rd }}\right.$ and $4^{\text {th }}$ year levels?), the researcher used t-test. 
Table 7. Respondents' acquisition of the selected of prepositions of time ordered by rank according to their year-level

\begin{tabular}{|c|c|c|c|c|}
\hline Preposition & Rank & Number & Mean & S.D. \\
\hline \multirow[t]{5}{*}{$a t$} & 1 & 79 & .55 & .267 \\
\hline & 2 & 56 & .66 & .232 \\
\hline & 3 & 43 & .73 & .203 \\
\hline & 4 & 19 & .63 & .241 \\
\hline & Total & 197 & .63 & .251 \\
\hline \multirow[t]{5}{*}{ to } & 1 & 79 & .52 & .406 \\
\hline & 2 & 56 & .65 & .329 \\
\hline & 3 & 43 & .70 & .310 \\
\hline & 4 & 19 & .55 & .339 \\
\hline & Total & 197 & .60 & .365 \\
\hline \multirow[t]{5}{*}{ in } & 1 & 79 & .51 & .258 \\
\hline & 2 & 56 & .59 & .264 \\
\hline & 3 & 43 & .62 & .275 \\
\hline & 4 & 19 & .50 & .333 \\
\hline & Total & 197 & .56 & .273 \\
\hline \multirow[t]{5}{*}{ for } & & 79 & .54 & .350 \\
\hline & & 56 & .53 & .346 \\
\hline & & 43 & .59 & .345 \\
\hline & & 19 & .51 & .338 \\
\hline & & 197 & .54 & .345 \\
\hline \multirow[t]{5}{*}{ after } & 1 & 79 & .46 & .288 \\
\hline & 2 & 56 & 588 & .294 \\
\hline & 3 & 43 & .56 & .304 \\
\hline & 4 & 19 & .42 & .277 \\
\hline & Total & 197 & .52 & .297 \\
\hline \multirow[t]{5}{*}{ before } & 1 & 79 & .45 & .313 \\
\hline & 2 & 56 & .53 & .329 \\
\hline & 3 & 43 & .54 & .327 \\
\hline & 4 & 19 & .51 & .338 \\
\hline & Total & 197 & .50 & .323 \\
\hline \multirow[t]{5}{*}{ during } & 1 & 79 & .41 & .322 \\
\hline & 2 & 56 & .44 & .323 \\
\hline & 3 & 43 & .52 & .317 \\
\hline & 4 & 19 & .46 & .280 \\
\hline & Total & 197 & .45 & .318 \\
\hline \multirow[t]{5}{*}{ from } & 1 & 79 & .42 & .329 \\
\hline & 2 & 56 & .38 & .316 \\
\hline & 3 & 43 & .55 & .333 \\
\hline & 4 & 19 & .47 & .322 \\
\hline & Total & 197 & .44 & .329 \\
\hline \multirow[t]{5}{*}{ since } & 1 & 79 & .37 & .320 \\
\hline & 2 & 56 & .45 & .280 \\
\hline & 3 & 43 & .53 & .334 \\
\hline & 4 & 19 & .30 & .307 \\
\hline & Total & 197 & .42 & .318 \\
\hline \multirow[t]{5}{*}{ on } & 1 & 79 & .32 & .277 \\
\hline & 2 & 56 & .45 & .273 \\
\hline & 3 & 43 & .47 & .290 \\
\hline & 4 & 19 & .50 & .236 \\
\hline & Total & 197 & .41 & .282 \\
\hline \multirow[t]{5}{*}{ while } & 1 & 79 & .40 & .304 \\
\hline & 2 & 56 & .46 & .256 \\
\hline & 3 & 43 & .44 & .289 \\
\hline & 4 & 19 & .30 & .229 \\
\hline & Total & 197 & .41 & .283 \\
\hline \multirow[t]{5}{*}{ until } & 1 & 79 & .27 & .254 \\
\hline & 2 & 56 & .29 & .245 \\
\hline & 3 & 43 & .35 & .295 \\
\hline & 4 & 19 & .22 & .262 \\
\hline & Total & 197 & .29 & .263 \\
\hline
\end{tabular}

As shown in table 7, it includes the rank order of the respondents' acquisitions of Prepositions of time according to the academic year level. 
Table 8. Significance of respondents' acquisition of the prepositions of time attributed to year-level

\begin{tabular}{|c|c|c|c|c|c|}
\hline Preposition & Preposition of Time & Sum of Squares & Mean Square & F. & Sig. \\
\hline \multirow[t]{3}{*}{ at } & Between Group & 1.030 & .343 & 5.873 & .001 \\
\hline & Within Group & 14.169 & .058 & & \\
\hline & Total & 14.636 & & & \\
\hline \multirow[t]{3}{*}{ to } & Between Group & 1.172 & .391 & 3.026 & .031 \\
\hline & Within Group & 24.911 & .129 & & \\
\hline & Total & 26.082 & & & \\
\hline \multirow[t]{3}{*}{ in } & Between Group & .466 & .155 & 2.118 & .099 \\
\hline & Within Group & 14.169 & .073 & & \\
\hline & Total & 14.636 & & & \\
\hline \multirow[t]{3}{*}{ for } & Between Group & .116 & .039 & .321 & .810 \\
\hline & Within Group & 23.183 & .120 & & \\
\hline & Total & 23.299 & & & \\
\hline \multirow[t]{3}{*}{ after } & Between Group & .785 & .262 & 3.061 & .024 \\
\hline & Within Group & .16 .502 & .086 & & \\
\hline & Total & 17.287 & & & \\
\hline \multirow[t]{3}{*}{ before } & Between Group & .292 & .097 & .934 & .425 \\
\hline & Within Group & 20.145 & .104 & & \\
\hline & Total & 20.437 & & & \\
\hline \multirow[t]{3}{*}{ during } & Between Group & .336 & .112 & 1.108 & .347 \\
\hline & Within Group & 19.494 & .101 & & \\
\hline & Total & 19.830 & & & \\
\hline \multirow[t]{3}{*}{ from } & Between Group & .713 & .238 & 2.241 & .085 \\
\hline & Within Group & 20.457 & .106 & & \\
\hline & Total & 21.170 & & & \\
\hline \multirow[t]{3}{*}{ since } & Between Group & 1.104 & .368 & 3.801 & .011 \\
\hline & Within Group & 18.677 & .097 & & \\
\hline & Total & 19.780 & & & \\
\hline \multirow[t]{3}{*}{ on } & Between Group & 1.030 & .343 & 4.537 & .004 \\
\hline & Within Group & 14.608 & .076 & & \\
\hline & Total & 15.638 & & & \\
\hline \multirow[t]{3}{*}{ while } & Between Group & .401 & .134 & 1.691 & .170 \\
\hline & Within Group & 15.257 & .079 & & \\
\hline & Total & 15.658 & & & \\
\hline \multirow[t]{3}{*}{ until } & Between Group & .289 & .096 & 1.408 & .242 \\
\hline & Within Group & 13.218 & .068 & & \\
\hline & Total & 13.508 & & & \\
\hline
\end{tabular}

Table 8 indicates that there is a significant difference among students' acquisition of the prepositions of time due to (year-level) in three prepositions (at, to, since) in favor of the third-year level students. This finding is neither assumed nor expected. The fourth-year level students' acquisition of prepositions according to this finding is lower than the third year level students. The researcher attributes this result to probable cheating when the students were asked to fill out the questionnaire which was in the form of a test. The findings also indicate that there is a significant statistical difference among the respondents' acquisition of the preposition of time (on) in favor of the fourth year-level students. The findings also reveal there is a significant difference among the respondents' acquisition of the preposition of time (after) in favor of the second year-level students at $(\alpha=0.05)$.

In answering the third question (Are there significant differences at $(\alpha=0.05)$ level of the acquisition of the selected prepositions of time among English major undergraduates at Balqa Applied University attributed to the college?), the researcher used t-test. 
Table 9. Respondents' acquisition of the prepositions of time ordered by rank according to the mean and the college

\begin{tabular}{ccccc}
\hline $\begin{array}{c}\text { Preposition of } \\
\text { Time }\end{array}$ & University College & Number & Mean & $\begin{array}{c}\text { Standard } \\
\text { Deviation }\end{array}$ \\
\hline \multirow{2}{*}{ at } & Ajlun & 117 & .66 & .240 \\
& Irbid & 80 & .59 & .262 \\
to & Ajlun & 117 & .59 & .369 \\
& Irbid & 80 & .62 & .360 \\
in & Ajlun & 117 & .53 & .293 \\
& Irbid & 80 & .60 & .237 \\
for & Ajlun & 117 & .54 & .384 \\
& Irbid & 80 & .56 & .342 \\
after & Ajlun & 117 & .51 & .292 \\
& Irbid & 80 & .51 & .305 \\
before & Ajlun & 117 & .48 & .318 \\
& Irbid & 80 & .52 & .331 \\
during & Ajlun & 117 & .48 & .310 \\
& Irbid & 80 & .41 & .327 \\
from & Ajlun & 117 & .46 & .333 \\
& Irbid & 80 & .42 & .323 \\
since & Ajlun & 117 & .44 & .322 \\
& Irbid & 80 & .40 & .312 \\
on & Ajlun & 117 & .43 & .292 \\
& Irbid & 80 & .38 & .267 \\
while & Ajlun & 117 & .43 & .286 \\
& Irbid & 80 & .39 & .278 \\
until & Ajlun & 117 & .29 & .253 \\
& Irbid & 80 & .29 & .277 \\
\hline
\end{tabular}

As shown in table 9, it includes the rank order and the means of the respondents' acquisitions of the prepositions of time according to college.

Table 10. Significance of the respondents' acquisition of the prepositions of time attributed to college

\begin{tabular}{|c|c|c|c|c|}
\hline \multirow{2}{*}{$\begin{array}{l}\text { Preposition } \\
\text { Time }\end{array}$} & \multirow[t]{2}{*}{ Variances } & \multicolumn{3}{|c|}{ T-Test for Equality of Means } \\
\hline & & $\mathrm{T}$ & Df & $\begin{array}{l}\text { Sig. (2- } \\
\text { tailed) }\end{array}$ \\
\hline \multirow[t]{2}{*}{ at } & Equal Variances Assumed & 1.840 & 195 & .067 \\
\hline & Equal Variances not Assumed & 1.810 & 159.847 & .072 \\
\hline \multirow[t]{2}{*}{ to } & Equal Variances Assumed & -.587 & 195 & .558 \\
\hline & Equal Variances not Assumed & -.590 & 172.545 & .556 \\
\hline \multirow[t]{2}{*}{ in } & Equal Variances Assumed & -1.752 & 195 & 1.081 \\
\hline & Equal Variances not Assumed & -1.823 & 189.520 & .070 \\
\hline \multirow[t]{2}{*}{ for } & Equal Variances Assumed & -.397 & 195 & .691 \\
\hline & Equal Variances not Assumed & -.399 & 171.710 & .691 \\
\hline \multirow[t]{2}{*}{ after } & Equal Variances Assumed & -.042 & 195 & .967 \\
\hline & Equal Variances not Assumed & -.042 & 165.021 & .967 \\
\hline \multirow[t]{2}{*}{ before } & Equal Variances Assumed & -.831 & 195 & .407 \\
\hline & Equal Variances not Assumed & -.825 & 165.302 & .411 \\
\hline \multirow[t]{2}{*}{ during } & Equal Variances Assumed & 1.622 & 195 & .107 \\
\hline & Equal Variances not Assumed & 1.606 & 163.957 & .110 \\
\hline
\end{tabular}




\begin{tabular}{lllll} 
from & Equal Variances Assumed & .852 & 195 & .395 \\
\multirow{4}{*}{ since } & Equal Variances not Assumed & .857 & 173.398 & .393 \\
& Equal Variances Assumed & .778 & 195 & .437 \\
on & Equal Variances not Assumed & .783 & 173.247 & .435 \\
& Equal Variances Assumed & 1.150 & 195 & .252 \\
while & Equal Variances not Assumed & 1.170 & 179.509 & .242 \\
& Equal Variances Assumed & .819 & 195 & .414 \\
until & Equal Variances not Assumed & .823 & 173.194 & .411 \\
& Equal Variances Assumed & -.057 & 195 & .955 \\
& Equal Variances not Assumed & -.056 & 159.756 & .956 \\
\hline
\end{tabular}

Table 10 indicates that there are no significant differences among students' acquisition of the prepositions of time due to university college. The researcher attributes this finding to the fact that the respondents' at both colleges (Ajloun and Irbid) belong to the same university (Balqa Applied University); they also study the same courses and syllabuses and most of them come from public schools.

In answering the fourth question (Are there significant differences at $(\alpha=0.05)$ level of the acquisition of the selected prepositions of time among English major undergraduates at Balqa Applied University attributed to the course "Basic English Grammar" whether studied by the respondents or not?), the researcher used t-test.

Table 11. Respondents' acquisition of the prepositions of time according to whether they studied the "Basic English Grammar" course

\begin{tabular}{|c|c|c|c|c|}
\hline $\begin{array}{l}\text { Preposition of } \\
\text { Time }\end{array}$ & $\begin{array}{l}\text { Whether the Respondents } \\
\text { Studied the Course or not }\end{array}$ & Number & Mean & S.D. \\
\hline \multirow[t]{2}{*}{ at } & Yes & 160 & .66 & .245 \\
\hline & No & 37 & .51 & .243 \\
\hline \multirow[t]{2}{*}{ to } & Yes & 160 & .62 & .360 \\
\hline & No & 37 & .51 & .375 \\
\hline \multirow[t]{2}{*}{ in } & Yes & 160 & .55 & .274 \\
\hline & No & 37 & .58 & .270 \\
\hline \multirow[t]{2}{*}{ for } & Yes & 160 & .55 & .347 \\
\hline & No & 37 & .51 & .336 \\
\hline \multirow[t]{2}{*}{ after } & Yes & 160 & .52 & .299 \\
\hline & No & 37 & .47 & .290 \\
\hline \multirow[t]{2}{*}{ before } & Yes & 160 & .50 & .317 \\
\hline & No & 37 & .48 & .350 \\
\hline \multirow[t]{2}{*}{ during } & Yes & 160 & .47 & .308 \\
\hline & No & 37 & .35 & .346 \\
\hline \multirow[t]{2}{*}{ from } & Yes & 160 & .47 & .329 \\
\hline & No & 37 & .32 & .305 \\
\hline \multirow[t]{2}{*}{ since } & Yes & 160 & .44 & .329 \\
\hline & No & 37 & .35 & .253 \\
\hline \multirow[t]{2}{*}{ on } & Yes & 160 & .42 & .291 \\
\hline & No & 37 & .36 & .240 \\
\hline \multirow[t]{2}{*}{ while } & Yes & 160 & .44 & .282 \\
\hline & No & 37 & .29 & .254 \\
\hline \multirow[t]{2}{*}{ until } & Yes & 160 & .30 & .263 \\
\hline & No & 37 & .24 & .260 \\
\hline
\end{tabular}

As shown in table 11, it includes the numbers of the students who studied the Basic English grammar course and those who did not study it. 
Table 12. Significance of the respondents' acquisition of the prepositions of time attributed to whether they studied "Basic English Grammar" course

\begin{tabular}{|c|c|c|c|c|}
\hline \multirow{2}{*}{ Preposition of Time } & \multirow[t]{2}{*}{ Variances } & \multicolumn{3}{|c|}{ T-Test for Equality of Means } \\
\hline & & $\mathrm{T}$ & Df & Sig. (2-tailed) \\
\hline \multirow[t]{2}{*}{ at } & Equal Variances Assumed & 3.305 & 195 & .001 \\
\hline & Equal Variances not Assumed & 3.325 & 54.303 & .002 \\
\hline \multirow[t]{2}{*}{ to } & Equal Variances Assumed & 1.739 & 195 & .084 \\
\hline & Equal Variances not Assumed & 1.695 & 52.461 & .096 \\
\hline \multirow[t]{2}{*}{ in } & Equal Variances Assumed & -.623 & 195 & .534 \\
\hline & Equal Variances not Assumed & -.628 & 54.496 & .532 \\
\hline \multirow[t]{2}{*}{ for } & Equal Variances Assumed & .736 & 195 & .462 \\
\hline & Equal Variances not Assumed & .752 & 55.235 & .455 \\
\hline \multirow[t]{2}{*}{ after } & Equal Variances Assumed & 1.028 & 195 & .305 \\
\hline & Equal Variances not Assumed & 1.047 & 55.111 & .300 \\
\hline \multirow[t]{2}{*}{ before } & Equal Variances Assumed & .396 & 195 & .692 \\
\hline & Equal Variances not Assumed & .372 & 50.519 & .711 \\
\hline \multirow[t]{2}{*}{ during } & Equal Variances Assumed & 2.123 & 195 & .035 \\
\hline & Equal Variances not Assumed & 1.974 & 50.022 & .054 \\
\hline \multirow[t]{2}{*}{ from } & Equal Variances Assumed & 2.466 & 195 & .015 \\
\hline & Equal Variances not Assumed & 2.582 & 56.933 & .012 \\
\hline \multirow[t]{2}{*}{ since } & Equal Variances Assumed & 1.491 & 195 & .138 \\
\hline & Equal Variances not Assumed & 1.755 & 67.361 & .084 \\
\hline \multirow[t]{2}{*}{ on } & Equal Variances Assumed & .985 & 195 & .326 \\
\hline & Equal Variances not Assumed & 1.111 & 63.027 & .271 \\
\hline \multirow[t]{2}{*}{ while } & Equal Variances Assumed & 3.001 & 195 & .003 \\
\hline & Equal Variances not Assumed & 3.208 & 58.476 & .002 \\
\hline \multirow[t]{2}{*}{ until } & Equal Variances Assumed & 1.186 & 195 & .237 \\
\hline & Equal Variances not Assumed & 1.194 & 54.305 & .238 \\
\hline
\end{tabular}

Studying the effect of whether "Basic English Grammar" course studied by the respondents or not on the acquisition of the prepositions of time. Tables (11) and (12) the findings indicate that there are significant differences among the respondents' acquisition of the prepositions of time (at, during, from, while) attributed to studying the course "Basic English Grammar" in favor of the respondents who studied the Basic English Grammar course at $(\alpha=0.05)$ level. This finding is reasonable and satisfactory. It is assumed that students who have studied Basic English Grammar course would do better in a preposition test than the students who have not studied that course.

\subsection{Recommendations}

Based on the findings of the research paper, the researcher concludes this with the following recommendations:

1) It is recommended that in order to promote learners' autonomy and to encourage them to master prepositions of time, university instructors of English language should point out the similarities between English and Arabic to facilitate learning for Arab EFL learners.

2) University instructors of English language may facilitate learning prepositions of time if they use equivalents used in the students' mother tongue, which is Arabic.

3) Teaching English prepositions of time to Arab EFL learners should be based on understanding the different meanings of Arabic prepositions. This may result in eliminating the misuse of many English prepositions.

4) University instructors should point out the differences between Arabic prepositions and English prepositions because such differences cause a lot of problems for Arab EFL learners of English, such as using the translation method, the interference form Arabic language which has been found the main cause of errors. Usage of prepositions in English is different from Arabic prepositions quite a lot and the Arabic prepositions are much fewer in number. 
5) University instructors should use the strategy of practice in teaching preposition. Such strategy will help Arab EFL learners of English master the usage of prepositions. Devoting more time to this strategy in instruction of prepositions helps learners gain self-confidence and encourages them to improve their English.

6) Further research is recommended to be conducted on teaching and learning English prepositions of time, place and direction. Comparative studies should be carried out on prepositions in Arabic and English.

\section{References}

Abbas, H. (1961). Al-Nahw Al-Wafi. Cairo; Dar Al-Maaref.

Abbas, M., \& Karimnia, A. (2011). An Analysis of grammatical errors among Iranian translation students: Insights from interlanguage theory. European Journal of Social Sciences, 25(4), 525-536. Retrieved from http://www.europeanjournalofsocialsciences.com

Agoi, F. (2003). Towards effective use of english: A grammar of modern English. Ibadan, Joytal Printing Press.

Alayesh, M. A. (2012). The effect of Arabic prepositions on the use of English prepositions. Managing knowledge and intellectual capital in higher education institutions in Egypt and Arab world, 11-12. April 2012, Mansura University.

Al. Marrani, Y. M. (2009). A Comparative and Contrastive Study of Prepositions in Arabic and English Language in India. Strength for Today and Bright Hope for Tomorrow, 9(7).

Boquist, Patricia. (2009). The Second Language Acquisition of English Prepositions, Liberty University (unpublished thesis).

Catalan, R. M. (1996). Frequency and Variability in Errors in the Use of English Prepositions. Miscellanea: $A$ Journal of English and American Studies, 17, 171-187.

Fion, Ko, Y. M. (2005). The acquisition of English spatial prepositions by ESL learners. unpublished thesis. The Chinese University of Hong Kong.

Grubic, B. (2004). Those problematic English prepositions. Retrieved from http://www.bobgrabic.com/seminar\%handout\%final.pdf

Hamdallah, R., \& Tushyeh, Hanna. (1988). A contrastive analysis of selected English and Arabic prepositions with pedagogical implications.

Hashim, N. (1996). English syntactic errors by Arabic speaking learners reviewed. Eric, Doc, 423660 Full Text.

Hayden, R. E. (1956). Mastering American English. A Handbook-Workbook of Essentials. Englewood Cliffs, N.J: Prentice Hall.

Jalali, H., \& Shojaei, M. (2012). Persian EFL students' developmental versus fossilized prepositional errors. The Reading Matrix, 12(1), 80-97.

Kharma, N., \& Hajjaj, A. (1997). Errors in English among Arabic speakers. Beirut: Librairie du Libnan.

Mathews, P. (1997). Concise dictionary of linguistics. New York: Oxford University Press.

Onike, Rahman. (2007). Analysis of errors of prepositions of the learners' use of English in second language situation. Retrieved from http://searchwarp.com/swall29884.htm

Scott, M., \& Tucker, G. R. (1974). Error Analysis and English Language Strategies of Arab Students. Language Learning, 24, 69-97. http://dx.doi.org/10.1111/j.1467-1770.1974.tb00236.x

Sudhakaran, B. (2008). The Use of Prepositions among Malay Adult ESL Learners. Unpublished doctoral thesis, University Putra Malaysia.

Tahaineh, Y. S. (2010). Arab EFL University students' errors in the use of prepositions. MJALZ, 2(1), January, 2010 .

Thahir, M. (1987). A contrastive analysis of some syntactic features in English and Arabic. Unpublished doctoral dissertation, Indiana: University of Indiana at Bloomington.

Zughoul, M. R. (1979). Teaching English prepositions. English Teaching Forum, 17, 24-29. 


\section{Copyrights}

Copyright for this article is retained by the author(s), with first publication rights granted to the journal.

This is an open-access article distributed under the terms and conditions of the Creative Commons Attribution license (http://creativecommons.org/licenses/by/3.0/). 